\title{
TITLE:
}

\section{A leopard ate a chimpanzee: First evidence from East Africa}

AUTHOR(S):

Nakazawa, Nobuko; Hanamura, Shunkichi; Inoue, Eiji; Nakatsukasa, Masato; Nakamura, Michio

CITATION:

Nakazawa, Nobuko ...[et al]. A leopard ate a chimpanzee: First evidence from East Africa. Journal of human evolution 2013, 65(3): 334-337

ISSUE DATE:

2013-05-21

URL:

http://hdl.handle.net/2433/174307

RIGHT:

(c) 2013 Elsevier Ltd.; この論文は出版社版でありません。引用の際には 出版社版をご確認ご利用ください。; This is not the published version. Please cite only the published version. 
1 Title: A leopard ate a chimpanzee: The first evidence from East Africa

2

3 Names of Authors: Nobuko NAKAZAWA a , Shunkichi HANAMURA ${ }^{\mathrm{a}}$, Eiji INOUE ${ }^{\mathrm{b}}$,

4 Masato NAKATSUKASA $^{\mathrm{b}}$, Michio NAKAMURA ${ }^{\mathrm{a}}$

5

6 Affiliations:

$7 \quad$ a'Wildlife Research Center, Kyoto University, Japan

$8 \quad$ braduate School of Science, Kyoto University, Japan

9

10 Short Title: A leopard ate a chimpanzee

12 Corresponding Author:

13 Nobuko NAKAZAWA, Ms.

14 Wildlife Research Center, Kyoto University

15 2-24, Tanaka-Sekiden-cho, Sakyo, Kyoto, 606-8203, JAPAN

16 Phone:+81-75-771-4399; E-mail: nakazawa.nobuko.62u@st.kyoto-u.ac.jp

18 Keywords: Leopard, chimpanzee, Mahale, predation, scavenging 


\section{Introduction}

Primates may have suffered predation pressures throughout their evolutionary history.

Hominoids have been sympatric with large carnivores since the early Miocene in Africa

(Werdelin and Peigné, 2010), and it is thought that predation pressure by large carnivores has played a significant role in their evolution (Hart and Sussman, 2005). For example, carnivore predation on Proconsul has been inferred from site R114 (“Pot-hole”) on Rusinga Island, Kenya, where the partial skeleton of P. heseloni KNM-RU 2036 was recovered (Walker and Shipman, 2005). In addition to fossil evidence, data on predation on living primates is also important for reconstructing the predation pressure on our human ancestors. Among potential nonhuman predators of living African apes, leopards (Panthera pardus) and lions (Panthera leo) have been known to actually prey upon apes. There has been only one report of lion predation on apes (Tsukahara, 1993). Lions are usually allopatric with apes because they are absent from tropical rainforests (Nowell and Jackson, 1996) where the majority of apes live. On the other hand, because leopards occur in most parts of sub-Saharan Africa (ibid.), they may be more likely than lions to prey upon apes. There has been limited information on leopard predation on apes, and all data have 
chimpanzees (Pan troglodytes schweinfurthii) at several sites in East Africa, no

instances of leopard predation have been reported. This is probably because of the

recent extirpation of leopards from most of the research sites. According to personal

communications from experienced field researchers, there has been no evidence of the

presence of leopards for a decade or more at the research sites of Gombe (Wilson ML)

DR), and Budongo (Newton-Fisher NE) in Uganda. The only exception is Mahale in

Tanzania where leopards have lived sympatrically with chimpanzees, without evidence

of predation by the former on the latter (Nishida 2012). There have been several reports

of encounters between leopards and chimpanzees from Tanzania including Mahale

(reviewed in Pierce, 2009). Responses of chimpanzees to leopards varied from emitting

loud, fearful calls, vigilance, and acting in a threatening manner (e.g., Pierce, 2009);

stalking a leopard that had called in the distance (Mitani JC, personal communication);

to surrounding a den and killing a cub (Hiraiwa-Hasegawa et al., 1986).

populations face little or no predation pressure. Although he recognized the presence of 
the consumption of an eastern chimpanzee at Mahale. Here, we report the details of this evidence.

\section{Methods}

We collected leopard scats in the Mahale Mountains National Park, Tanzania (Nishida, 2012) for 41 days in June-August 2012. Although other large carnivores (lions, hunting dogs, and hyenas) are reported to inhabit the park, no direct or indirect evidence of the former 2 species has been observed in the study area for more than 2 decades (also, no domestic dogs have been confirmed in the area). Hyena scats were observed in 2005 and 2008 but were distinguishable from those of leopards by its very whitish appearance and finer digestion of bones. Thus, it is unlikely that we misidentified leopard scats with

66 those of other species. We walked observation trails within the home range of the habituated M group chimpanzees (387 min/day on average). When a scat was found, we

68 recorded its location with GPS and carried it back to our camp. After being dried and weighed, we inspected its contents for hair, bones, and skin. To confirm whether the contents were of chimpanzees, we conducted morphological investigations and DNA analysis. Taxonomic identification was based on previous work on comparative primate postcranial morphology (Ward et al., 1995; Nakatsukasa et al., 2003). DNA was 
extracted from a small bone using a TBONE EX KIT (DNA Chip Research Inc., Japan)

and a 331-base pair segment of the mitochondrial hypervariable control region (Inoue et al., 2011) was analyzed. We also examined the XY homologous gene amelogenin for sex identification and 8 microsatellite loci for individual identification (Inoue et al., 2008).

\section{Results}

We collected 142 leopard scats, among which one contained the right and left patellae,

81 the distal end of a manual proximal phalanx, and an intact manual intermediate phalanx of a chimpanzee (Fig. 1). The patellae are morphologically similar and almost identical in size. The completely fused proximal epiphysis of the intermediate phalanx, morphology of the ligamentous insertion on the patella and modestly developed flexor sheath ridges on the phalanges suggest these bones belonged to an adult (not old), and probably a female based on general size and robusticity criteria. The distal part is chewed off and trabeculae are exposed dorsally in both patellae (Fig. $1 \mathrm{a}, \mathrm{b}$ ). The break surface is mediolaterally long and gently concave. The dorsal (= posterior) break edge is more proximal than in the ventral (= anterior) break edge, which approximates the original distal border. The missing part includes the whole attachment area of the 
91 patellar ligament. The cut surface suggests that the leopard filled its mouth with the distal part of the quadriceps femoris muscles and the patella and tried to cut off the mouth infill from the remaining carcass. Probably, the patella (and the ligament) was not fully turned over, and the leopard's carnassials could not reach the patellar ligament but only the ligament attachment area. The right patella also has a bite mark on the lateral rim (Fig. 1 b). There is no gnaw mark on the intermediate phalanx (Fig. 1 c).

97 Along the proximal epiphysis of the intermediate phalanx, the cortex is damaged, probably caused by the acid (or acidotic erosion and physical stress). The break on the proximal phalanx is a common fracture pattern. The scat was found on June 18, 2012, at the beginning of the dry season. It was not very fresh but estimated to be no older than 4 months from its appearance and the extent of preceding rainfalls (the main factor in scat decay). The location (Fig. 2) is within the M group’s home range and is used exclusively by the group (Nakamura et al., 2013). We had seen and heard evidence of leopards (foot prints, roars, etc.) on 10 different days within the preceding month. On June 13, a field assistant had observed a

106 leopard and night guards said they frequently observed leopards around that time. Five M group chimpanzees that had disappeared within the preceding 4 months were potential candidates for the victim. DNA profiles of these candidates or of 
109 their mothers were available (Table 2). Analyses of DNA extracted from a phalanx of

110 the victim (hereafter "Bone2012”) reconfirmed that Bone2012 was actually a female

111 chimpanzee. Her mitochondrial haplotype was B, a common haplotype in the M group

112 (Inoue et al., 2011), but among candidates, only a male AG had this haplotype.

113 Microsatellite analyses also showed that two candidates (CA and TZ) had different

114 alleles from Bone 2012 at 5 or more loci. Mothers of 3 other candidates (AG, ME, and

115 TZ09) did not share alleles with Bone2012 at 2 loci. Therefore, we conclude that

116 Bone2012 was not an individual from the M group.

\section{Discussion}

119 We confirmed that a leopard ate an adult female chimpanzee at Mahale. This is the first evidence of leopard consumption of eastern chimpanzees (P. t. schweinfurthii), which

121 adds another subspecies to the list of apes consumed by leopards. from the group. Because the home range of a different chimpanzee group reaches to approximately $1 \mathrm{~km}$ north of the scat location, a small distance compared to known leopard range sizes (Jenny, 1996), the leopard may have eaten a chimpanzee of that 
127 have eaten an unknown female right after her emigration from her natal group to the $\mathrm{M}$

128 group. If the leopard actually killed the victim, this means that a leopard can prey on a

129 full adult female chimpanzee. Female chimpanzees are smaller in body size, less

130 aggressive, and less gregarious than males, and thus could be more prone to predation.

131 The predation risk would be even higher when females transfer alone between

132 unit-groups. Thus, we might need to take such potential risk from female transfer into

133 account when discussing how a female-dispersal social structure, like that of

134 chimpanzees, could have evolved.

research sites have as many leopards as in the Taï forest, we found comparable, or even

be cautious about direct comparisons because research efforts might differ. Evidence of sightings per year at Taï (Boesch and Boesch-Achermann, 2000, Table A.2), we cannot conclude that leopards are rarer in Mahale than in Taï. 
145 occasional leopard attacks on chimpanzees. In 2009, one male chimpanzee had a much

146 deeper wound than usually caused by fights among male conspecifics. Further, in 2011,

147 a mother-infant pair was found injured and the mother had 3 long, parallel scars from

148 the head to the back, seemingly caused by claws. Because researchers had thought that

149 leopards did not eat chimpanzees at Mahale (Nishida, 2012), they had assumed that all

150 serious injuries came from intraspecific fights. Now, because there has been confirmed

151 leopard consumption of a chimpanzee, we should also consider attacks by leopards as a

152 possible cause of injury or death for Mahale chimpanzees. Again, if the victim was

153 actually killed by a leopard, this means that predation pressure has been underestimated

154 for more than 40 years at Mahale or, alternatively, that leopards have recently shifted

155 their diet to include chimpanzees. If the former is the case, this might imply a wider

156 underestimation of predation pressures on primates in general. Because predation events

157 are rarely observable but can still be significant to primates’ behavioral and social

158 evolution, we might need to acquire a better picture of carnivore-primate relationships

159 with long-term data. The ecology and behavior of Mahale leopards have yet to be

160 studied. Because information on predation pressure on living apes is still too scarce to

161 be used to infer the predation pressure on fossil hominins, we may need to investigate

162 further the ecology and behavior of leopards that are currently sympatric with apes. 


\section{Acknowledgements}

165 We thank the Tanzania Commission for Science and Technology, Tanzania Wildlife

166 Research Institute, Tanzania National Parks, and the Mahale Mountains Wildlife

167 Research Centre for permissions to conduct this research at Mahale; Drs. C Hashimoto,

168 JC Mitani, NE Newton-Fisher, T Struhsaker, ML Wilson, and Mr. DR Mills for

169 information about leopards in their study sites; Dr. N Itoh, for her cooperation in the

170 field; and Dr. J Keyyu, for logistic support; and the journal editors and anonymous

171 reviewers for valuable comments on our manuscript. This research was financially

172 supported by the Primate Origins of Human Evolution Program of the JSPS to NN, the

173 JSPS Research Fellowship for Young Scientists (\#244 to SH), and the Grants-in-Aid for

174 Scientific Research (\#24255010 to J. Yamagiwa).

\section{References}

Bailey, T.N., 1993. The African Leopard. Columbia University Press, New York.

178 Boesch, C., 1991. The effect of leopard predation on grouping patterns in forest chimpanzees. Behaviour 117, 220-242.

180 Boesch, C., 2009. The Real Chimpanzee. Cambridge University Press, Cambridge. 
181 Boesch, C., Boesch-Achermann, H., 2000. The Chimpanzees of the Taï Forest. Oxford 182 University Press, Oxford.

183 D’Amour, D.E., Hohmann, G., Fruth, B., 2006. Evidence of leopard predation on 184 bonobos (Pan paniscus). Folia Primatol. 77, 212-217.

185 Fay, J.M., Carroll, R., Kerbis Peterhans, J.C, Harris, D., 1995. Leopard attack on and 186 consumption of gorillas in the Central African Republic. J. Hum. Evol. 29, 93-99.

187 Furuichi, T., 2000. Possible case of predation on a chimpanzee by a leopard in the Petit Loango Reserve, Gabon. Pan Afr. News 7, 21-23.

Hart, D., Sussman, R. W., 2005. Man the Hunted. Westview Press, Boulder.

Henschel, P., Abernethy, K.A., White, L.J.T., 2005. Leopard food habits in the Lopé National Park, Gabon, Central Africa. Afr. J. Ecol. 43, 21-28.

Hiraiwa-Hasegawa, M., Bryne, R.W., Takasaki, H., Bryne, J.M., 1986. Aggression toward large carnivores by wild chimpanzees of Mahale Mountains National Park, Tanzania. Folia Primatol. 47, 8-13.

Hoppe-Dominik, B., 1984. Etude du spectre des proies de la panthère, Panthera pardus, dans le Parc National de Taï en Côte d’Ivoire. Mammalia 48, 477-488. 
197 Inoue, E., Inoue-Murayama, M., Vigilant, L., Takenaka, O., Nishida, T., 2008.

198 Relatedness in wild chimpanzees: influence of paternity, male philopatry, and

199 demographic factors. Am. J. Phys. Anthropol. 137, 256-262.

200 Inoue, E., Tashiro,Y., Ogawa,H., Inoue-Murayama, M., Nishida,T., Takenaka, O., 2011.

201 Gene flow and Genetic diversity of chimpanzees in Tanzania Habitats. Primate

$202 \quad$ Conserv.

http://www.primate-sg.org/storage/pdf/PC26_Inoue_et_al_chimps_Tanzania.pdf

Jenny, D., 1996. Spatial organization of leopards Panthera pardus in Taï National Park,

Nakamura, M., Corp, N., Fujimoto, M., Fujita, S., Hanamura, S., Hayaki, H., Hosaka,

Kooriyama, T., Marchant, L.F., Matsumoto-Oda, A., Matsusaka, T., McGrew, W.C.,

Mitani, J.C., Nishie, H., Norikoshi, K., Sakamaki, T., Shimada, M., Turner, L.A.,

212 Nakatsukasa, M., Kunimatsu, Y., Nakano, Y., Takano, T., Ishida, H., 2003. Comparative 
215 Nishida, T., 2012. Chimpanzees of the Lakeshore. Cambridge University Press,

216 Cambridge.

217 Nowell, K., Jackson, P., 1996. Wild Cats. IUCN, Cambridge.

218 Pierce, A.H., 2009. An encounter between a leopard and a group of chimpanzees at

219 Gombe National Park. Pan Afr. News. 16.

220 Tsukahara, T., 1993. Lions eat chimpanzees: The first evidence of predation by lions on

221 wild chimpanzees. Am. J. Primatol. 29, 1-11.

222 Walker, A., Shipman, P., 2005. The Ape in the Tree. Cambridge, Mass. Belknap Press.

223 Ward, C.V., Ruff, C.B., Walker, A., Rose, M.D., Teaford, M.F., Nengo, I.O., 1995.

224 Functional morphology of Proconsul patellas from Rusinga Island, Kenya, with

225 implications for other Miocene-Pliocene catarrhines. J. Hum. Evol. 29, 1-19.

226 Werdelin, L., Peigné, S., 2010. Carnivore. In: Werdlin L., Sanders W.J., (Eds.),

227 Cenozoic Mammals of Africa. University of California Press, Berkeley. pp. 603-657.

228 Zuberbühler, K., Jenny, D., 2002. Leopard predation and primate evolution. J. Hum.

229 Evol. 43, 873-886.

230 
Table 1 Reported leopard predation/consumption of African apes

\begin{tabular}{|c|c|c|c|c|}
\hline \multirow[t]{2}{*}{ Study site (Country) } & \multirow[t]{2}{*}{ Species/subspecies } & \multicolumn{2}{|c|}{ Evidence of predation } & \multirow[t]{2}{*}{ Source } \\
\hline & & Leopard scats $^{1}$ & Indirect evidence & \\
\hline \multirow[t]{4}{*}{ Taï (Côte d’Ivoire) } & Pan troglodytes verus & 0/215 (15 months) & Three deaths possibly by & Hoppe-Dominik, 1984 \\
\hline & & 1/200 (1 year) & leopards & Boesch 1991; 2009, \\
\hline & & & & Zuberbühler and Jenny, \\
\hline & & & & 2002 \\
\hline Dzanga-Sangha & Gorilla gorilla gorilla & $\mathrm{Yes}^{2}$ & N/A & Fay et al., 1995 \\
\hline \multicolumn{5}{|l|}{ (Central African } \\
\hline \multicolumn{5}{|l|}{ Republic) } \\
\hline \multirow[t]{2}{*}{ Lopé (Gabon) } & G. g. gorilla & 6/196 (8 years) & N/A & Henschel et al., 2005 \\
\hline & P. t. troglodytes & 4/196 (8 years) & & \\
\hline Petit Loango (Gabon) & P. t. troglodytes & N/A & Leopard scats and footprints & Furuichi, 2000 \\
\hline & & & near chimpanzee corpse & \\
\hline Lui Kotal & P. paniscus & Yes $^{2}$ & N/A & D’Amour et al., 2006 \\
\hline \multirow{2}{*}{\multicolumn{5}{|c|}{ (Democratic Republic }} \\
\hline & & & & \\
\hline
\end{tabular}


Table 2 DNA profile of the chimpanzee bone found in a leopard scat in comparison with those of M group chimpanzees that

235 disappeared in 2012

\begin{tabular}{|c|c|c|c|c|c|c|c|c|c|c|c|}
\hline \multirow{2}{*}{$\begin{array}{l}\text { Names of } \\
\text { chimpanzees }\end{array}$} & \multirow{2}{*}{$\begin{array}{c}\text { Age } \\
\text { (years) }\end{array}$} & \multirow[t]{2}{*}{ Sex } & \multirow{2}{*}{$\begin{array}{c}\text { Mitochondrial } \\
\text { haplotype }^{1}\end{array}$} & \multicolumn{8}{|c|}{ Microsatellite loci ${ }^{1}$} \\
\hline & & & & D9s910 & D11s2002 & D2s1329 & D12s66 & D2s1326 & D5s1470 & D7s2204 & D7s817 \\
\hline Bone2012 & adult? & F & B & $104 / 104$ & $148 / 148$ & $178 / 202$ & & $182 / 218$ & $190 / 190$ & $245 / 249$ & $116 / 116$ \\
\hline \multicolumn{12}{|l|}{ Candidates } \\
\hline CA & $52^{3}$ & F & $\underline{\mathrm{C}}$ & $\underline{104 / 110}$ & $\underline{148 / 156}$ & $\underline{182 / 198}$ & 158/182 & $\underline{182 / 186}$ & & $\underline{249 / 253}$ & $\underline{112 / 124}$ \\
\hline $\mathrm{TZ}$ & $30^{3}$ & $\mathrm{~F}$ & $\underline{\mathrm{A}}$ & $\underline{104 / 110}$ & $148 / 148$ & $\underline{178 / 198}$ & $154 / 154$ & $\underline{202 / 206}$ & $\underline{186 / 190}$ & $245 / 249$ & $\underline{144 / 148}$ \\
\hline $\mathrm{AG}^{2}$ & 7 & $\underline{\mathrm{M}}$ & B & $104 / 104$ & $148 / 148$ & $178 / 182$ & $150 / 182$ & $150 / 182$ & $\underline{194 / 194}$ & $245 / 253$ & $\underline{148 / 152}$ \\
\hline $\mathrm{ME}^{2}$ & 10 & F & $\underline{\mathrm{C}}$ & $104 / 113$ & $148 / 148$ & $\underline{186 / 198}$ & $182 / 182$ & $182 / 182$ & $186 / 190$ & $249 / 249$ & $\underline{148 / 152}$ \\
\hline $\mathrm{TZO9}^{2}$ & 2 & F & $\underline{\mathrm{A}}$ & $104 / 110$ & $148 / 148$ & 178/198 & $154 / 154$ & 202/206 & $186 / 190$ & $245 / 249$ & $\underline{144 / 148}$ \\
\hline
\end{tabular}

$237 \quad{ }^{2}$ DNA data from their mothers are shown because their own DNA is not available. A mother shares a mitochondrial haplotype and at least one allele at all 238 loci with offspring.

$239{ }^{3}$ Estimated age

240 Underlined data show mismatches with Bone 2012. 
$242 \quad$ Figure 1

243

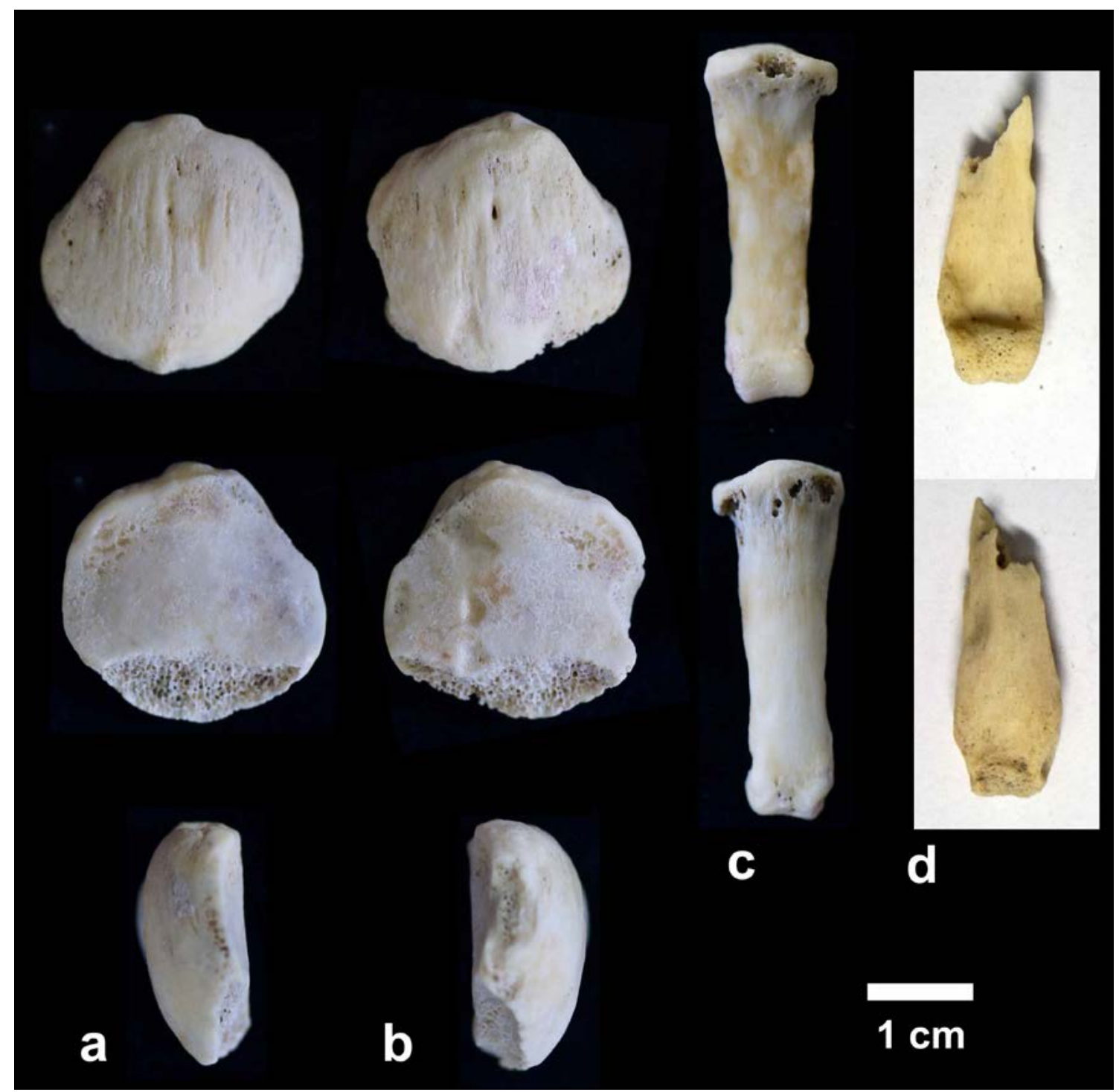


Figure 2

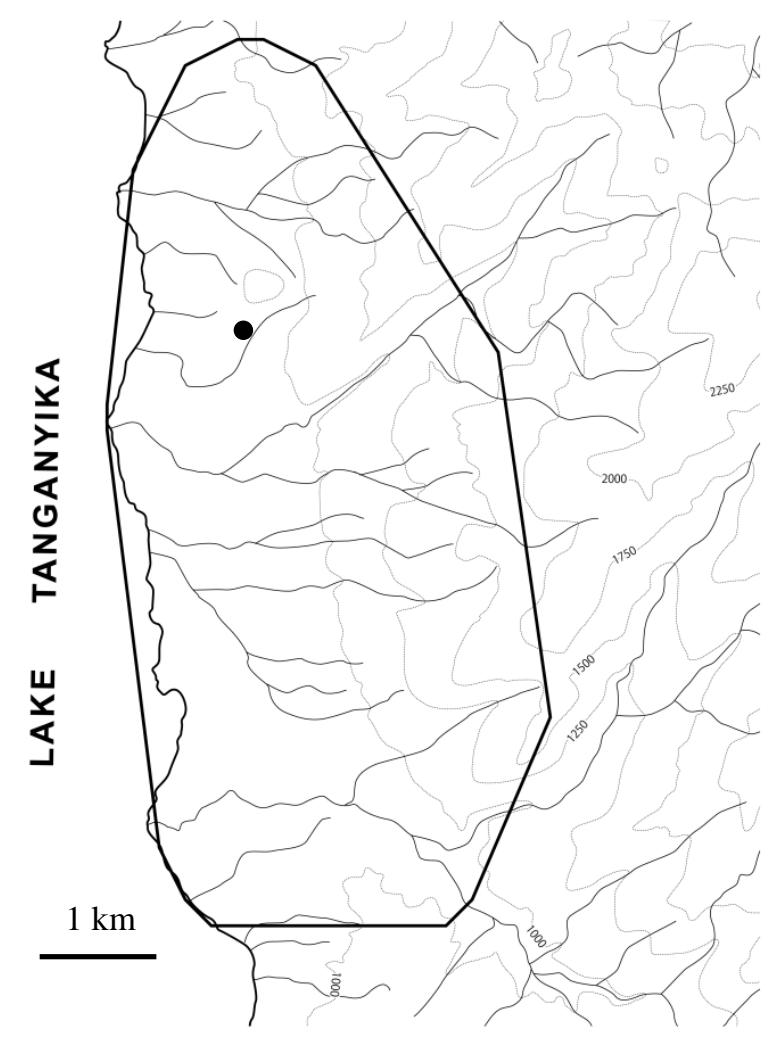




\section{Figure Legends}

250 Figure 1. Recovered chimpanzee bones. a, b: left and right patellae, respectively (from

251 top to bottom: anterior, posterior, and lateral views). c: middle phalanx (top: palmar

252 view). d: distal fragment of a proximal phalanx (top: palmar view).

253

254 Figure 2. The location where the leopard scat with chimpanzee bones was found (black

255 dot) in relation to the home range of the M group chimpanzees (a polygon). 